Review

\title{
Pharmacological screening of Eryngium foetidum Linn - A Review
}

Galamula Hewage Tharuka
Kanchana Hemachandra ${ }^{1}$
Sinnadurai Thuvaragan ${ }^{*}$ 'D
Vinotha Sanmugarajah ${ }^{2}$
'Department of Pharmacy, Faculty of
Allied Health Sciences, University of
Jaffna, Jaffna, Northern Province, Sri
Lanka
2Unit of Siddha Medicine, University of
Jaffna, Jaffna, Northern Province, Sri
Lanka
*email: sthuvaragan@univ.jfn.ac.lk
Keywords:
Activities
Eryngium foetidum
Pharmacology
Review

\begin{abstract}
Eryngium foetidum L. (Family Apiaceae) is a biennial herb, and it is used as a culinary herb and spice across the different countries of the world, including Sri Lanka, India, Bangladesh, Malaysia, Singapore, etc. due to its high aroma quality. Also, it is used to treat several ailments, such as respiratory diseases, gastrointestinal ailments, and skin diseases among different indigenous populations for its medicinal properties. Based on ethnomedical evidence, many studies have been conducted to identify the phytoconstituents, underlying mechanisms, and related pharmacological effects of different parts of this plant. This study reviewed the current state of findings related to the Pharmacological activities of E. foetidum. Based on this review, this plant is widely used for ethnomedical and culinary purposes. Pharmacological screening of the plant revealed that it had different activities such as anti-inflammatory, antioxidant, antimicrobial, anthelminthic, anticonvulsant, anticancer, antidiabetic, antimalarial, larvicidal, and hepatoprotective activities. This review further promised that potential new chemical entities could be elicited from the phytoconstituents of E. foetidum.
\end{abstract}

Received: June 28th, 2021

Accepted: October 24th, 2021

Published: November 30th, 2021

(c) 2021 Galamula Hewage Tharuka Kanchana Hemachandra, Sinnadurai Thuvaragan, Vinotha Sanmugarajah. Published by Institute for Research and Community Services Universitas Muhammadiyah Palangkaraya. This is an Open Access article under the CC-BY-SA License (http://creativecommons.org/licenses/by-sa/4.0/). DOI: https:// doi.org/10.33084/ bjop.v4i4.2377

\section{INTRODUCTION}

Eryngium is the largest and most complex genus in the Apiaceae family ${ }^{1}$, and it includes more than 250 flowering species worldwide. Under this genus, the most studied species have been Eryngium foetidum L., cultivated in Asian countries such as Iran, Turkey, Europe, Tropical Africa, and Pacific islands. Eryngium foetidum is native to Tropical America and the West Indies. It is used as a culinary herb and spice globally, including in Sri Lanka, India, Bangladesh, Malaysia, Singapore, and others. Eryngium foetidum is also considered a general edible food component in Nigeria ${ }^{2}$. Eryngium foetidum is commonly known as 'spiny coriander'3, 'spirit weed' or 'saw-tooth coriander' and is also called in different countries as langer koriander (German); ketumbar java (Malay); pak chi farang (Thai); ngo gai (Vietnamese); culantro, racao, recao (Spanish); Bahkhawr' (India) and andu kola (Sri Lanka) ${ }^{4}$. The leaves of this plant are frequently used interchangeably with Coriandrum sativum L. due to their similar pungent aroma character 5 . It treats several ailments, such as respiratory diseases, gastrointestinal ailments, and skin diseases, by different indigenous systems ${ }^{6}$.

A review study stated that the technology for mass production is available for this plant, cultivated for commercial purposes ${ }^{6}$. Simultaneously, it is easily propagated by seeds (germinate in 20-25 days) in spring or suckers during monsoon. The seedlings are ready to transplant in 45-50 days after seed sowing4. In Bangladesh, a research study provides a baseline of 
information concerning this plant's cultivation techniques, market potential, and climate resilience ${ }^{3}$.

Based on ethnomedical evidence, many studies have been explored phytoconstituents, underlying mechanisms, and related pharmacological effects of the different parts of this plant ${ }^{7}$. Still, many compounds actively responsible for different pharmacological effects of this plant are yet to be detected. Even though some therapeutic effects have been elicited using in vitro models, further studies will be needed to correlate these activities using in vivo models. This study reviews the current state of findings related to the Pharmacological screening of E. foetidum.

\section{PLANT CLASSIFICATION}

Classification and local names of E. foetidum are presented in Table I. This plant also has several synonyms, with many local names from various parts of the world. However, in general, this plant is better known as long coriander.

\begin{tabular}{|c|c|}
\hline Classification & Identity \\
\hline Domain & Eukaryote \\
\hline Kingdom & Plantae \\
\hline Phylum & Tracheophyta \\
\hline Class & Magnoliopsida \\
\hline Order & Apiales \\
\hline Family & Apiaceae \\
\hline Genus & Eryngium \\
\hline Species & Eryngium foetidum $\mathrm{L}$ \\
\hline Synonyms & $\begin{array}{l}\text { Eryngium antihystericum Rottler, Eryngium molleri } \\
\text { Gand }\end{array}$ \\
\hline $\begin{array}{l}\text { Common } \\
\text { name }\end{array}$ & $\begin{array}{l}\text { Long coriander, wild coriander, fitweed, culantro, } \\
\text { Mexican coriander }\end{array}$ \\
\hline English name & Long coriander/Sea Holly \\
\hline
\end{tabular}

\section{BOTANICAL DESCRIPTION}

Eryngium foetidum is a leafy herb and distributed in the tropical zone of the world. It is indigenous to tropical zones such as America and Caribbean islands, from southern Mexico to Panama via Brazil and from Cuba to Trinidad. It is generally grown in tropical areas like Africa, South Asia, Southern Europe, and the Pacific islands. It is extensively cultivated in Costa Rica and Puerto Rico for its usage and exporting to the US4.

A biennial pungently smelling herb and E. foetidum (Figure 1) consists of fleshy waxy in nature, oblanceolate shape, $30 \mathrm{~cm}$ long and $4 \mathrm{~cm}$ broad serrated or dentate margin with dark green leaves; each tooth of the margin has a slight yellow spine spirally arranged around a short thick stem from a basal rosette. Flowers white, sessile and bisexual, white, narrow, oblonged and notched petals; corolla-creamy white with green calyx, sepals are tubular, acute, persistent, longer than petals and forming an umbel inflorescence on a long stalk, which arises from the leaf rosette at the bottom; fruits are globose to ovoid and evenly branched fibrous roots ${ }^{6}$.

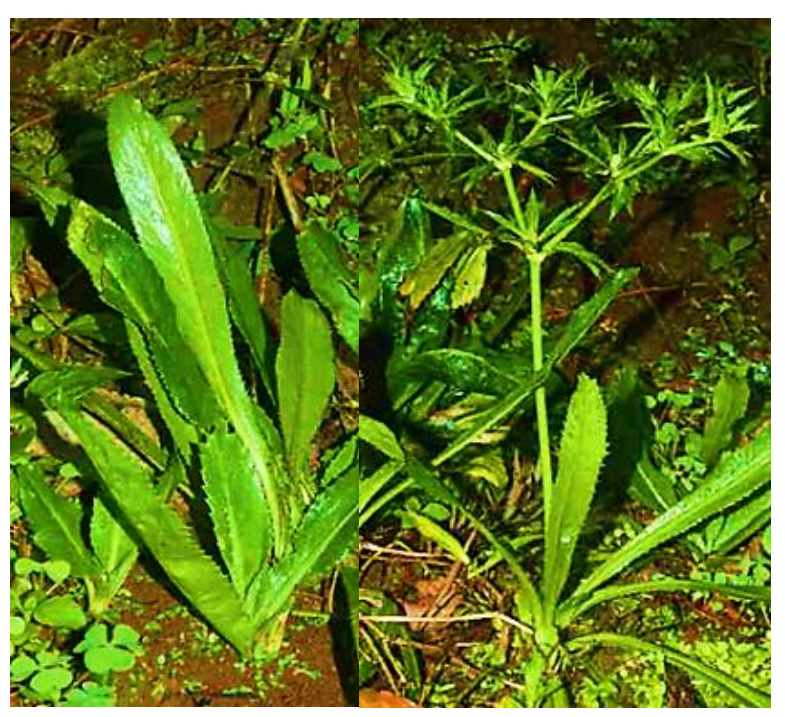

Figure 1. Eryngium foetidum plant

\section{TRADITIONAL-ETHNOMEDICAL USE}

Eryngium foetidum has been widely used in Southeast Asian countries, Caribbean islands, and Latin America, where its harvested leaves are commonly used in foods 7 . In traditional medicine, the leaves and roots have been used to treat insanity, skin diseases, mucosal diseases, pulmonary ailments, diabetes mellitus, stomach disorders, and conditions related to the nervous system, such as convulsions, paralysis, spasms, and pains ${ }^{9}$. Moreover, it is used as a vermifuge and febrifuge ${ }^{10}$. 
Eryngium foetidum has been used to treat colds and fever, burns, earache ${ }^{11}$, pneumonia, flu, convulsions in children, malaria ${ }^{12}$, hypertension, constipation, worm infections, and infertility complications ${ }^{13}$. The roots have stomachic, sudorific, and diuretic effects ${ }^{13,14}$, where leaf juice/decoction stimulates the gut as a laxative7. It was also reported to treat several poisons, including the treatment of snake bites and scorpion-sting venom ${ }^{4,13}$.

In West Africa, aerial parts of this plant were used to treat respiratory diseases (asthma, cough, cold, and sinusitis), gastrointestinal ailments such as diarrhea, and crushed leaves in heated palm oil to treat rheumatism ${ }^{15}$. Tea or infusions prepared from the leaves of this plant were used as an inhalation to alleviate respiratory disorders ${ }^{12}$. In traditional Chinese medicine, E. foetidum is widely used for the treatment of inflammation².

\section{PHYTOCHEMICAL ANALYSIS}

Phytochemical screening of this plant found several secondary metabolites such as flavonoids, phenols, tannins, saponins, ascorbic acid, and terpenoids ${ }^{16,17}$. Leaves are an excellent source of vitamin $\mathrm{A}^{18}$. Mabeku et al. ${ }^{19}$ found that the methanol extracts of leaves of $E$. foetidum contained alkaloids, phenols, flavonoids, anthraquinones, and sterol. However, another study explored the presence of flavonoids, tannins, saponin, coumarins, and triterpenoid and the absence of alkaloids in the plant's leaves ${ }^{1,6,20}$. The chloroform extracts of dried aerial parts by soxhlet extraction followed by chromatographic fractionation yielded a pentacyclic triterpenoid saponin and O-glycoside ${ }^{21}$. Some free triterpenoids were too identified from leaves' hexane extract, including stigmasterol-the main phytosterol22,23. Eryngium foetidum is a rich source of phenolic compounds $5,24,25$. Leitão et al. ${ }^{26}$ found that the E. foetidum leaves showed major carotenoids as all-trans-lutein and all-trans- $\beta$-carotene and major phenolic compounds as chlorogenic acid and ferulic acid. The major constituent (E)-2-dodecenal with 14 compounds was identified in chloroform and methanol leaf extracts of E. foetidum via HPLC analysis. Moreover, another study found that the ethanol extracts E. foetidum shows higher flavonoid contents ${ }^{27}$.

Dried leaves yielded 0.1 to $0.95 \%$ of essential oil ${ }^{18}$. Gas chromatography-mass spectroscopy (GC-MS) analysis of essential oil identified 63 different compounds ${ }^{24}$. The linear unsaturated aldehyde, (E)-2-dodecenal was reported as the main constituent in the aldehydes, which were identified as the major constituents of the essential oil of E. foetidum ${ }^{6,12,1,242-25,28-32}$. A study showed that the (E)2-dodecenal was responsible for the fruity, sweet, sour, and characteristic "cilantro" aroma of this plant with the highest flavor dilution factor ${ }^{33}$. The monoterpene hydrocarbons $^{5}$ and positional isomers of trimethylbenzaldehyde ${ }^{29}$ were present as the highest constituents from the stem and root essential oil of $E$. foetidum, respectively.

Seeds of E. foetidum yielded $0.2 \%$ of essential oil in which carotol (19.3\%) was identified as the main constituent ${ }^{34}$. Acharya et al. ${ }^{35}$ investigated the phytochemical analysis of $E$. foetidum found in coastal Odisha, India, and revealed that leaves and branches of E. foetidum consisted of chiefly 10-undecenal followed by 2,4,6-trimethylbenzaldehyde, (Z)-9-tetradecenal, and (Z)-7-tetradecenal. This study further suggested that the chemo profile of E. foetidum and seasonal C. sativum were the same, and E. foetidum can be used as an alternative to seasonal C. sativum. Structures of different chemical constituents of the leaves, stem, and root of E. foetidum were given in the appendix ${ }^{5,24-25,34}$.

\section{PHARMACOLOGICAL ACTIVITIES}

Some compounds like (E)-2-dodecenal or 'Eryngial,' which present abundantly in E. foetidum, revealed to have 
multiple bio-activities, and numerous studies revealed that the E. foetidum has anti-inflammatory, antioxidant, antimicrobial, antifungal, anti-helminthic, anti-tumor, anti-diabetic, antimalarial larvicidal and anticonvulsant activities. These activities are summarized in Table II.

\section{Anti-inflammatory activity}

Several studies explored the anti-inflammatory activity of the plant with pathways of mechanisms responsible for the activity ${ }^{36}$. The hexane extract from the leaves of $E$. foetidum has shown possible anti-inflammatory activity ${ }^{3}$. Prior treatment with ethanol extract of E. foetidum leaf inhibited the elevation of interleukin 6 (IL-6), tumor necrosis factor-alpha (TNF-a), inducible nitric oxide synthase (iNOS), and cyclooxygenase (COX-2), together with their cognate messenger ribonucleic acid (mRNAs) in a dose-dependent manner. Nitric oxide (NO) and intracellular reactive oxygen species (ROS) contents were similarly reduced. This result suggested that E. foetidum leaf extract possesses suppressive effects on proinflammatory mediators, and the plant has the potential to reduce the risk of cancer associated with inflammation ${ }^{37}$. Leaf extract of E. foetidum consisted of lutein, $\beta$-carotene, chlorogenic acid, kaempferol, and caffeic acid, which had bioactive properties ${ }^{38}$.

The aqueous bioaccessible fraction of leaves of E. foetidum, prepared from simulated digestion, has inhibited IL-8 and MCP-1 levels in the human intestinal Caco-2 cells, which were stimulated with interleukin-1 $\beta$ (IL-1 $)$. Here, lipophilic constituents such as lutein and beta-carotene had a major role in the anti-inflammatory activity. Further study suggested that the consumption of $E$. foetidum could prevent intestinal inflammation 38,39 .

The topical anti-inflammatory activity of E. foetidum was studied in the TPA-induced mice; it was evident with the inhibition of myeloperoxidase (MPO) enzyme activity by hexane extract of E. foetidum ${ }^{40}$. Oral administration of decoction of E. foetidum inhibited carrageenan-induced edema in rat paws and TPA-induced edema in the ears of mice. Further, this extract potently inhibited the abdominal writhing induced by acetic acid ${ }^{41}$. In India, the North East Institute of Science and Technology developed a drug formulation for treating arthritis and skin disease in which the essential oil of E. foetidum is one of the main components ${ }^{4}$.

\section{Antioxidant activity}

Numerous studies have been conducted to evaluate the antioxidant activity of the plant. A study revealed that pretreatment with E. foetidum leaf extract (35-140 $\mu \mathrm{g} / \mathrm{ml})$ inhibited ROS generation mediated by NADPH oxidase in lipopolysaccharide (LPS)-induced mice ${ }^{37}$. Ethanol extract of the E. foetidum leaves exhibited $51.44 \%$ radical scavenging activity, correlated with a high level of phenolic and flavonoid contents ${ }^{42}$. Amazonian $E$. foetidum has shown that the scavenging capacity of methanol leaves extract against ABTS and $\mathrm{DPPH}^{26}$. Another study also proved the remarkable scavenging activity of methanol leaf extract against DPPH and FRAP assay $^{27}$.

The oxygenated compounds like 2,4,6-trimethylphenol, linear saturated aliphatic alcohols, unsaturated aliphatic alcohols, and aliphatic aldehyde compounds of essential oil from the stem were identified as enhancers of antioxidant activity ${ }^{43}$, and $78.08 \%$ of radical scavenging activity was observed with the essential oil extracted from the stem of E. foetidum, which were comparable with the activity of standard ascorbic acid 5 . The active polar principles such as chlorogenic acid, caffeic acid, and kaempferol-phenolics in a bioaccessible fraction of $E$. foetidum extract have reduced intracellular ROS accumulation in the IL-1 $\beta$ stimulated Caco-2 cells ${ }^{38}$. Methanol extract of E. foetidum shows the highest antioxidant activity compare to aqueous and chloroform extracts $^{44}$. The DPPH assay revealed that the methanol extract has higher antioxidant activity than saponin and 
essential oils from leaves of E. foetidum, and also, the saponin of this plant has been shown to have antioxidant activity ${ }^{45}$. According to these results, the leaf and stem of E. foetidum have significant antioxidant properties, which vary due to the different methods of the extraction process $^{46}$. The Nigerian E. foetidum volatile oils have shown that the potential source of natural antioxidants is the high acyclic aldehydes and aromatic compounds ${ }^{47}$. Moreover, a study found that these essential oil compounds from Colombian E. foetidum have antioxidant capacity against DPPH assay ${ }^{25}$. The methanolic extract of leaves of E. foetidum showed high antimicrobial activity, which could be related to the high concentration of polyphenols and flavonoids ${ }^{48}$.

\section{Antibacterial activity}

Methanol and chloroform extracts from $E$. foetidum leaves highly inhibited Streptococcus pneumoniae, Staphylococcus aureus, and Listeria monocytogenes (Gram positives bacteria), while aqueous extract highly inhibited Salmonella typhimurium (Gram-negative bacteria) ${ }^{44}$. Methanol extract showed a dose-dependent, mild to moderate antibacterial activity against $S$. aureus, while it was ineffective against any tested Gram-negative organisms (Escherichia coli and Pseudomonas aeruginosa) ${ }^{49}$. Another study was done with methanol, ethanol, and aqueous extracts from leaves of E. foetidum, S. aureus, Pseudomonas oleovorans, Klebsiella pneumoniae, Salmonella enteric, and E. coli were sensitive to at least one extract. At the same time, Bacillus megaterium, Bacillus subtilis, and Bacillus flexus were sensitive to all three extracts ${ }^{50}$. Another study reported that the blanched E. foetidum leaf suspension $(10 \% \mathrm{w} / \mathrm{v})$ with $100 \%$ growth inhibition in tested S. aureus and B. subtilis ${ }^{51}$. The methanol and ethanol extracts of the E. foetidum have shown a quite similar and good antibacterial potential to the aqueous extracts ${ }^{42}$. Pretreatment with essential oil of E. foetidum as an antimicrobial agent at $15 \mathrm{mg} / \mathrm{L}$ concentrations reduced the pasteurization temperatures of pineapple juice to $60^{\circ} \mathrm{C}$, where customarily conducted at 80 to $95^{\circ} \mathrm{C}$ for 15 to 30 seconds. Due to the antibacterial effect of E. foetidum essential oil, there is inactivation of L. monocytogenes ${ }^{28}$.

Ndip et al.22 found that the methanol extract from $E$. foetidum leaves showed moderate antibacterial activity against six clinical strains of Helicobacter pylori out of 15 tested strains, using the disk diffusion method. Another study has shown that the methanol extract of E. foetidum has anti-helicobacter activity in vitro and in vivo compared to ciprofloxacin ${ }^{19}$. The $\mathrm{ZnO}$ nanoparticles prepared by incorporating leaf extracts of E. foetidum showed broadspectrum antibacterial activity ${ }^{52}$. The polyacetylenes of this plant also demonstrated antibacterial abilities ${ }^{1}$. Most of the studies evaluate the antibacterial activity of extracts only. Further studies need to evaluate the antibacterial activity of isolated phytoconstituents ${ }^{53}$.

\section{Antifungal activity}

Leaf and stem extracts of $E$. foetidum inhibited some fungi including Candida albicans, Candida guilliermondi, and Cryptococcus neoformans with minimum inhibitory concentrations of 256,1024 , and $32 \mu \mathrm{g} / \mathrm{mL}$, respectively. Additionally, this extract showed a significant inhibitory effect towards strains of C. neoformans ${ }^{54}$. However, relatively few tests were carried out on fungi compared to bacteria.

\section{Anti-helminthic activity}

The methanol extract of E. foetidum exhibited a dosedependent helminthicidal activity against Paramphistomum $\mathrm{sp}^{13}$. In another in vitro study using the infective larvae at the $3^{\text {rd }}$ stage of Strongyloides stercoralis, E. foetidum showed the most effectiveness at a $50 \mathrm{mg} / \mathrm{mL}$ concentration among 25 Jamaican herbal extracts. Eryngial (trans-2-dodecenal) possessed anti-helminthic activity against infective larvae of $S$. stercoralis and was significantly more effective than ivermectin as a comparison drug 5 . 


\section{Anti-tumor activity}

Extracts from E. foetidum can reduce the risk factors of cancer development associated with different inflammatory mediators. Inhibition of TNF- $\alpha$ expression by $E$. foetidum leaf extract would be helpful in cancer prevention involving reducing invasiveness of cancer cells $^{37}$. This plant can also inhibit cell division, which is another significant controlling factor in tumor development ${ }^{39}$. The essential oil and methanol extract of leaves had selective inhibition towards the proliferation of PC-3 and A-549 cell lines ${ }^{45}$. Another study revealed no clastogenicity associated with freeze-dried leaves of $E$. foetidum and has anticlastogenic potential in mice using erythrocyte micronucleus assay. This study further suggested the potential health benefit of E. foetidum leaves ${ }^{55}$.

\section{Anti-diabetic activity}

Eryngium foetidum leaf extracts showed a amylase inhibitory activity in vitro56. Further, in vivo studies reported the reduced blood glucose levels (comparable to glibenclamide) in streptozotocin-induced diabetic rat models at doses of 250 and $500 \mathrm{mg} / \mathrm{kg}$ of the extract ${ }^{57}$. A study reported $52.2 \%$ inhibition of a-amylase activity using E. foetidum ethanol extract, where the slightest inhibition was observed with an aqueous extract ${ }^{22}$. Kusirisin et al. .58 revealed that E. foetidum potentially prevents glycation associated with diabetes subjects. However, another study found that the aqueous extract E. foetidum was ineffective as an anti-hyperglycaemic agent on STZ induced rat models subjected to oral glucose tolerance test $\mathrm{t}^{59}$. Another study mentioned that the E. foetidum plants of Manipur, India, could be used as herbal remedies for the treatment of diabetes mellitus ${ }^{42}$.

\section{Antimalarial activity}

A survey on the use of herbal remedies for malaria and leishmaniasis in Loreto of Peru reported that boiled plant material from E. foetidum had been used to treat malaria/leishmaniasis. Nevertheless, in vitro study was unable to confirm such activity ${ }^{60}$. However, another study identified that E. foetidum had an in vitro antiplasmodial activity with $\mathrm{IC}_{50}$ more than $25 \mu \mathrm{g} / \mathrm{mL}$ when traditionally using antimalarial herbal medications among Quechua and Mestizo populations native to Loreto in Peru-were tested against parasite cultures ${ }^{61}$. Ruiz et al..$^{62}$ found in vitro study that this plant has an antimalarial potential with $\mathrm{IC}_{50}$ of more than $10 \mu \mathrm{g} / \mathrm{ml}$, where 59 locally using plants to treat malaria in Nanay river banks of Peru.

Aqueous extracts of the whole plant of E. foetidum have shown an anti-plasmodial activity against Plasmodium gallinaceum in vivo, in chicken models, where 476 plants from the American continent were reviewed activity against different strains of plasmodium ${ }^{63}$. Both $n$-hexane and ethyl acetate fractions from extracts of aerial parts of E. foetidum showed anti-leishmanial activity against Leishmania tarentolae and Leishmania donovani ${ }^{64}$. An extract rich in eryngial was patented for the treatment of parasites in humans and other mammals ${ }^{65,66}$.

\section{Larvicidal activity}

As much as $3 \%$ of brine shrimp larvae mortality was identified with aqueous and methanol extracts of $E$. foetidum, showed no mortality; 226 amazonian plants were tested to determine their lethal effect on brine shrimp larvae (nauplii) in an in vitro assay ${ }^{67}$. An in vitro study reported that the crude extract of this plant achieved 100\% mortality against mosquito larva after 24 hours. Further, this study suggested that terpenes present in these plants could be the reason for this mosquito larvicidal activity ${ }^{68}$. Sumitha et al. ${ }^{9}$ reported that the essential oil from aerial parts of this plant could be effectively used against fourth-instar Aedes albopictus larvae, in which $90 \%$ of larvicidal activity was exhibited. Further, this study emphasizes using this plant's essential oil as a natural insecticide with minimum side effects on 
humans. Crude extract of E. foetidum showed the most toxic activity against the mosquito larvae. This plant can be used as a substitute for mosquito repellent coils ${ }^{70}$.

\section{Anti-convulsant activity}

This plant has been extensively used in traditional medicine to treat fits in Jamaica ${ }^{71,72}$. In an in vivo study, intraperitoneal administration of the extract of $E$. foetidum with the concentration of $110 \mathrm{~g} / 250 \mathrm{~mL}$ showed antiepileptic activity against picrotoxin-induced convulsions in rats ${ }^{73,74}$. The aqueous extract of chopped $E$. foetidum leaves, when given orally at a dose of 100 $\mathrm{mg} / \mathrm{kg}$, was effective against picrotoxin-induced convulsions in albino rats ${ }^{71}$. Furthermore, Nsour et al. ${ }^{73}$ reported that intraperitoneal injection of aqueous extracts of leaves and stem of E. foetidum, in rat models, exhibited anticonvulsant effects equal to phenobarbital.

Table II. Pharmacological activities of different parts of $E$.

\begin{tabular}{|c|c|c|}
\hline Parts & Preparation / extract & Activities \\
\hline \multirow[t]{19}{*}{ Leaves } & $n$-hexane & Anti-inflammatory 40 \\
\hline & Ethanol & Anti-inflammatory ${ }^{37}$ \\
\hline & $\begin{array}{l}\text { Aqueous } \\
\text { bioaccessible fraction }\end{array}$ & Anti-inflammatory ${ }^{38}$ \\
\hline & Methanol & Antioxidant ${ }^{26,27,44,45,52}$ \\
\hline & $\begin{array}{l}\text { Methanol, water \& } \\
\text { chloroform }\end{array}$ & Antibacterial $^{44}$ \\
\hline & Methanol & Antibacterial ${ }^{19,22,49}$ \\
\hline & $\begin{array}{l}\text { Methanol, ethanol \& } \\
\text { aqueous }\end{array}$ & Antibacterial ${ }^{42}$ \\
\hline & Methanol \& ethanol & Antibacterial $^{42}$ \\
\hline & Essential oil & Antibacterial $^{28}$ \\
\hline & $\begin{array}{l}\text { Aqueous extract in } \\
\mathrm{ZnO} \text { nanoparticles }\end{array}$ & Antibacterial $^{52}$ \\
\hline & Methanol & Antifungal ${ }^{54}$ \\
\hline & Methanol & Anti-helminthic ${ }^{13,50}$ \\
\hline & $\begin{array}{l}\text { Essential oil \& } \\
\text { methanol }\end{array}$ & Anti-tumor ${ }^{45}$ \\
\hline & Aqueous & Antidiabetic $^{57}$ \\
\hline & Ethanol & Antidiabetic ${ }^{42}$ \\
\hline & Aqueous & Antidiabetic ${ }^{58}$ \\
\hline & Aqueous & Anti-convulsant ${ }^{71,73,74}$ \\
\hline & Freeze dried leaves & Anticlastogenic ${ }^{55}$ \\
\hline & $\begin{array}{l}\text { Aqueous } \\
\text { bioaccessible fraction }\end{array}$ & Anti-inflammatory ${ }^{38}$ \\
\hline $\begin{array}{l}\text { Leaves } \\
\text { and stem }\end{array}$ & Essential oil & Antioxidant ${ }^{5,25,45}$ \\
\hline \multirow[t]{4}{*}{$\begin{array}{l}\text { Whole } \\
\text { plant }\end{array}$} & Methanol & $\begin{array}{l}\text { Antifungal \& } \\
\text { antioxidant }{ }^{54}\end{array}$ \\
\hline & Aqueous & Antiplasmodial ${ }^{63}$ \\
\hline & Extract & Larvicidal $^{67,70}$ \\
\hline & Essential oil & Larvicidal $^{69}$ \\
\hline $\begin{array}{l}\text { Aerial } \\
\text { parts }\end{array}$ & $\begin{array}{l}n \text {-hexane and ethyl } \\
\text { acetate fractions }\end{array}$ & Antiplasmodial ${ }^{63}$ \\
\hline
\end{tabular}

\section{TOXICITY STUDIES}

The acute toxicity study of hydro-alcoholic extracts of $E$. foetidum did not show any morbidity, mortality, or post toxicity signs in albino mice, even at a dose of 2000 $\mathrm{mg} / \mathrm{kg}^{74}$. Chandira et al. ${ }^{77}$ reported that the oral dose at $2500 \mathrm{mg} / \mathrm{kg}$ of aqueous extract of E. foetidum was lethal for healthy, adult, and young rodents. Acute oral toxicity of methanolic extract of leaves of E. foetidum was studied using rats to which extract was fed. This study revealed that $\mathrm{LD}_{50}$ of the extract showed $2000 \mathrm{mg} / \mathrm{kg}$, and toxicity of the plant was extremely low upon oral administration ${ }^{48}$. Further genotoxicity of the methanolic extract of the plant revealed that plants protect damages to DNA induced by some substances. Also, the even higher concentration of extract did not produce DNA damages. It could be related to the higher antioxidant potential of the plant ${ }^{5}$.

Consumption of E. foetidum above $0.8 \%$, which is more than 35 times human consumption, resulted in weight loss, kidney and spleen damage, as demonstrated through chronic toxicity animal studies. Further elevation of blood urea nitrogen was observed due to kidney damage by renal tubular-nephrosis, interstitial nephritis, and spleen hemosiderosis due to toxic metabolites of E. foetidum ${ }^{76}$. Eryngium foetidum was influential in the amelioration of carbon tetrachlorideinduced hepatotoxicity in mice ${ }^{75}$. This study demonstrated the hepatoprotective potential of this plant. Furthermore, the compound 'eryngial' as the main constituent of essential oil of E. foetidum showed significant inhibition on enzyme cytochrome P450 2E16.

\section{CONCLUSION}

Eryngium foetidum $\mathrm{L}$ is a potential aromatic crop and is widely used for ethnomedical and culinary purposes. Furthermore, it exhibited many pharmacological applications such as anti-inflammatory, antioxidant, 
antimicrobial, anticonvulsant, antimalarial, anthelminthic, larvicidal, anticancer, anti-diabetic, and hepatoprotective activities with no cytotoxic effects. Even though several research studies were done to screen pharmacological activities, limited studies have been conducted to isolate and screen phytoconstituents of the plant. Studies should be focused on identifying the bioactives with potential activities. This review promised that potential new chemical entities could be elicited from phytoconstituents of E. foetidum, and also this plant can also be used as a substitute for mosquito repellent coils. Therefore, further studies should be done to prove this effect in the future.

\section{ACKNOWLEDGMENT}

None.

\section{AUTHORS' CONTRIBUTION}

\section{Galamula Hewage Tharuka Kanchana Hemachandra:} conceived and design the analysis, writing of the paper. Sinnadurai Thuvaragan: conceived and design the analysis. Vinotha Sanmugarajah: collected data, contributed data or analysis tools.

\section{DATA AVAILABILITY}

None.

\section{CONFLICT OF INTEREST}

The authors declare no conflict of interest.

\section{REFERENCES}

1. Parham S, Kharazi AZ, Bakhsheshi-Rad HR, Nur H, Ismail AF, Sharif S, et al. Antioxidant, Antimicrobial and Antiviral Properties of Herbal Materials. Antioxidants. 2020;9(12):1309.
2. Erdem SA, Nabavi SF, Orhan IE, Daglia M, Izadi M, nabavi SM. Blessings in disguise: a review of phytochemical composition and antimicrobial activity of plants belonging to the genus Eryngium. Daru. 2015;23:53. doi:10.1186/s40199-015-0136-3

3. Hossain MA, Jashimuddin M, Nath TK, O'Reilly P. Spiny coriander (Eryngium foetidum L.) cultivation in the Chittagong Hill Tracts of Bangladesh: Sustainable agriculture innovation by indigenous communities. Indian J Tradit Knowl. 2017;16(1):59-67. handle:123456789/37014

4. Singh BK, Ramakrishna Y, Ngachan SV. Spiny coriander (Eryngium foetidum L.): a commonly used, neglected spicing-culinary herb of Mizoram, India. Genet Resour Crop Evol. 2014;61:1085-90. doi:10.1007/s10722-014-0130-5

5. Thomas PS, Essien EE, Ntuk SJ, Choudhary MI. Eryngium foetidum L. Essential Oils: Chemical Composition and Antioxidant Capacity. Medicines. 2017;4(2):24. doi:10.3390/medicines4020024

6. Paul JHA, Seaforth CE, Tikasingh T. Eryngium foetidum L.: a review. Fitoterapia. 2011;82(3):302-8. doi:10.1016/j.fitote.2010.11.010

7. Geck MS, Cristians S, Berger-González M, Casu L, Heinrich M, Leonti M. Traditional Herbal Medicine in Mesoamerica: Toward Its Evidence Base for Improving Universal Health Coverage. Front Pharmacol. 2020;11:1160. doi:10.3389/fphar.2020.01160

8. Wunderlin RPBF, Hansen ARF, Essig FB. Atlas of Florida Plants [Internet]. (Landry SM, Campbell KN, USF Water Institute). Institute for Systematic Botany, University of South Florida, Tampa; 2021 [cited 2021 Jun 28]. Available from https:/ /florida.plantatlas.usf.edu/

9. DukeJA, Bogenschutz-Godwin MJ, duCellier J, Duke PAK. Handbook of Medicinal Herbs. 2nd ed. Florida (US): CRC Press; 2002.

10. Joshi RK, Satyal P, Setzer WN. Himalayan Aromatic Medicinal Plants: A Review of their Ethnopharmacology, Volatile Phytochemistry, and Biological Activities. Medicines. 2016;3(1):6. doi:10.3390/medicines3010006

11. Banout J, Havlik J, Kulik M, Kloucek P, Lojka B, Valterova I. Effect of solar drying on the composition of essential oil of sacha culantro (Eryngium foetidum L.) Grown in the peruvian amazon. J Food Process 
Eng. 2010;33(1):83-103. doi:10.1111/j.17454530.2008.00261.x

12. Martins AP, Salgueiro LR, da Cunha AP, Vila R, CañigueralS, Tomi F, et al. Essential Oil Composition of Eryngium foetidum from S. Tomé e Príncipe. J Essent Oil Res. 2003;15(2):93-5. doi:10.1080/10412905.2003.9712077

13. Swargiary A, Daimari A, Daimari M, Basumatary N, Narzary E. Phytochemicals, antioxidant, and anthelmintic activity of selected traditional wild edible plants of lower Assam. Indian J Pharmacol. 2016;48(4):418-23. doi:10.4103/0253-7613.186212

14. Wong KC, Feng MC, Sam TW, Tan GL. Composition of the Leaf and Root Oils of Eryngium foetidum L. J Essent Oil Res. 1994;6(4):369-74. doi:10.1080/10412905.1994.9698401

15. Xu Y, Liang D, Wang GT, Wen J, Wang RJ. Nutritional and Functional Properties of Wild FoodMedicine Plants from the Coastal Region of South China. J Evid Based Integr Med. 2020;25:2515690X20913267. doi:10.1177/2515690X20913267

16. Mabeku LBK, Flaurant TT, Jacques K. Screening of some Cameroonian Medicinal Plants against Bacterial and Yeasts involved in Gastrointestinal Disorders. Int J Biol. 2017;9(3):56-64. doi:10.5539/ijb.v9n3p56

17. Usharani L, Singh WRC, Surodhani S, Singh WN. Pharmacognostical evaluation and antibacterial activity of medicinally important spices occurred in local area of Manipur. Asian J Plant Sci Res. 2016;6(2):42-5.

18. Shavandi MA, Haddadian Z, Ismail MHS. Eryngium foetidum L. Coriandrum sativum and Persicaria odorata L.: A Review. J Asian Sci Res. 2012;2(8):41026.

19. Mabeku LBK, Bille BE, Ngeupi E. In Vitro and In Vivo Anti-Helicobacter Activities of Eryngium foetidum (Apiaceae), Bidens pilosa (Asteraceae), and Galinsoga ciliata (Asteraceae) against Helicobacter pylori. Biomed Res Int. 2016;2016:2171032. doi:10.1155/2016/2171032

20. Nataraj K, GirishaST, Raghavendra VB. Miracle plant Eryngium foetidum Linn- A review on Ethnobotanical, Phytochemical composition and Pharmacology. Int J Adv Sci Technol. 2020;29(2):1099115.
21. Anam EM. A novel triterpenoid saponin from Eryngium foetidum. Indian $\mathrm{J}$ Chem Sect B. 2002;41B:1500-3. handle:123456789/22011

22. Ndip RN, Tarkang AEM, Mbullah SM, Luma HN, Malongue A, Ndip LM, et al. In vitro antiHelicobacter pylori activity of extracts of selected medicinal plants from North West Cameroon. J Ethnopharmacol. 2007;114(3):452-7. doi:10.1016/j.jep.2007.08.037

23. Wang P, Su Z, Yuan W, Deng G, Li S. Phytochemical Constituents and Pharmacological Activities of Eryngium L. (Apiaceae). Pharm Crop. 2012;3:99-120. doi:10.2174/2210290601203010099

24. Chowdhury JU, Nandi NC, Yusuf M. Chemical Constituents of Essential Oil of the Leaves of Eryngium foetidum from Bangladesh. Bangladesh J Sci Ind Res. 2007;42(3):347-52. doi:10.3329/bjsir.v42i3.674

25. Jaramillo BE, Duarte E, Martelo I. Volatile chemical composition of the essential oil from colombian Eryngium foetidum L. and determination of its antioxidant activity. Rev Cubana Plant Med. 2011;16(2):140-50.

26. Leitãoa DdSTC, Siqueira FC, de Sousa SHB, Mercadante A, Chisté RC, Lopes AS. Amazonian Eryngium foetidum leaves exhibited very high contents of bioactive compounds and high singlet oxygen quenching capacity. Int J Food Prop. 2020;23(1):1452-64.

doi:10.1080/10942912.2020.1811311

27. Ashwaty PM, Saj OP. Carminative, Phytochemical and Antioxidant Potentialities of the Leaf Extracts of Eryngium foetidum L. (Apiaceae). World J Pharm Pharm Sci. 2014;3(6):2269-80.

28. Ngang JJE, Nyegue MA, Ndoye FC, Kamgain ADT, Kamdem SLS, Lanciotti R, et al. Characterization of Mexican coriander (Eryngium foetidum) essential oil and its inactivation of Listeria monocytogenes in vitro and during mild thermal pasteurization of pineapple juice. JFood Prot. 2014;77(3):435-43. doi:10.4315/0362028x.jp-13-323

29. Thi NDT, Anh TH, Thach LN. The Essential Oil Composition of Eryngium foetidum L. in South Vietnam Extracted by Hydrodistillation under Conventional Heating and Microwave Irradiation. J Essent Oil-Bear Plant. 2008;11(2):154-61. doi:10.1080/0972060X.2008.10643612 
30. Cardozo E, Rubio M, Rojas LB, Usubillaga A. Composition of the Essential Oil from the Leaves of Eryngium foetidum L. from the Venezuelan Andes. J Essent Oil Res. 2004;16(1):33-4. doi:10.1080/10412905.2004.9698645

31. Leclercq PA, Duñg NX, Lô VN, Toanh NV. Composition of the Essential Oil of Eryngium foetidum L. from Vietnam. J Essent Oil Res. 1992;4(4):423-4. doi:10.1080/10412905.1992.9698097

32. Yeh PH. Essential Oils XVI Oil of Eryngium Foetidum, Linn. J Chin Chem Soc. 1974;21(3):139-47. doi:10.1002/jccs.197400019

33. Quynh CTT, Kubota K. Aroma Constituents and Enzyme Activities of Japanese Long Coriander Leaves (Culantro, Eryngium foetidum L.). Food Sci Technol Res. 2012;18(2):287-94. doi:10.3136/fstr.18.287

34. Pino JA, Rosado A, Fuentes V. Chemical Composition of the Seed Oil of Eryngium foetidum L. from Cuba. J Essent Oil Res. 1997;9(1):123-4. doi:10.1080/10412905.1997.9700731

35. Acharya GC, Ponnam N, Kumari M, Roy TK, Shivashankara KS, Sahoo MR. Phytochemical profiling of spiny coriander (Eryngium foetidum L.) - A potential perennial spicing-culinary herb of eastern India. Acta Chromatogr. 2021;34(2):197-202. doi:10.1556/1326.2021.00909

36. Azab A, Nassar A, Azab AN. Anti-Inflammatory Activity of Natural Products. Molecules. 2016;21(10):1321. doi:10.3390/molecules21101321

37. Mekhora C, Muangnoi C, Chingsuwanrote P, Dawilai S, Svasti S, Chasri K, et al. Eryngium foetidum suppresses inflammatory mediators produced by macrophages. Asian Pac J Cancer Prev. 2012;13(2):653-64. doi:10.7314/арjсp.2012.13.2.653

38. Dawilai S, Muangnoi C, Praengamthanachoti P, Tuntipopipat S. Anti-Inflammatory Activity of Bioaccessible Fraction from Eryngium foetidum Leaves. Biomed Res Int. 2013;2013:958567. doi:10.1155/2013/958567

39. Suttisansanee U, Thiyajai $P$, Chalermchaiwat $P$, Wongwathanarat K, Pruesapan K, CharoenkiatkulS, et al. Phytochemicals and In Vitro Bioactivities of Aqueous Ethanolic Extracts from Common Vegetables in Thai Food. Plants. 2021;10(8):1563. doi:10.3390/plants10081563
40. García MD, Sáenz MT, Gómez MA, Fernández MA. Topical antiinflammatory activity of phytosterols isolated from Eryngium foetidum on chronic and acute inflammation models. Phytother Res. 1999;13(1):78-80. doi:10.1002/(sici)10991573(199902)13:1<78::AID-PTR384>3.0.CO;2-F

41. Sáenz MT, Fernández MA, García MD. Antiinflammatory and analgesic properties from leaves of Eryngium foetidum L. (Apiaceae). Phytother Res. 1998;11(5):380-3. doi:10.1002/(SICI)1099-1573(199708)11:5<380::AIDPTR116>3.0.CO;2-\%23

42. Malik T, Pandey DK, Roy P, Okram A. Evaluation of Phytochemicals, Antioxidant, Antibacterial and Antidiabetic Potential of Alpinia galanga and Eryngium foetidum Plants of Manipur (India). Pharmacogn J. 2016;8(5):459-64. doi:10.5530/pj.2016.5.8

43. Gyesi JN, Opoku R, Borquaye LS. Chemical Composition, Total Phenolic Content, and Antioxidant Activities of the Essential Oils of the Leaves and Fruit Pulp of Annona muricata L. (Soursop) from Ghana. Biochem Res Int. 2019;2019:4164576. doi:10.1155/2019/4164576

44. Dalukdeniya DACK, Rathnayaka RMUSK. Comparative Study on Antibacterial and Selected Antioxidant Activities of Different Eryngium foetidum Extracts. J Appl Life Sci Int. 2017;12(4):1-7. doi:10.9734/JALSI/2017/34378

45. Chandrika R, Jagath V, Thara-Saraswathi KJ. In Vitro Antioxidant and Anti-Proliferative Activities in Eryngium Foetidum L. Int J Pharm Res Health Sci. 2016;4(2):1110-6.

46. Mateos-Maces L, Chávez-Servia JL, Vera-Guzmán AM, Aquino-Bolaños EN, Alba-Jiménez JE, Villagómez-González BB. Edible Leafy Plants from Mexico as Sources of Antioxidant Compounds, and Their Nutritional, Nutraceutical and Antimicrobial Potential: A Review. Antioxidants. 2020;9(6):541. doi:10.3390/antiox9060541

47. Attah AF, Fagbemi AA, Olubiyi O, Dada-Adegbola $\mathrm{H}$, Oluwatudon A, Elujoba A, et al. Therapeutic Potentials of Antiviral Plants Used in Traditional African Medicine With COVID-19 in Focus: A Nigerian Perspective. Front Pharmacol. 2021;12:596855. doi:10.3389/fphar.2021.596855

48. Raunelli P, Liviac D, Alvis R, Puente S, Best I, Reategui O. Cytoprotective Effect of the Eryngium 
foetidum "Sacha Culantro" Methanolic Leaf Extract Versus Sodium Fluoride Exposed Mice using the Micronucleus Test and the Comet Assay. Pharmacogn J. 2019;11(3):461-5. doi:10.5530/pj.2019.11.72

49. Dutta S, Bhattacharjee A, Yadav M, Shougrakpam P, Monin RG, Das A, Devi MN. Antibacterial activity of spiny coriander (eryngium foetidum linn.) on gram positive and gram negative bacteria. Int J Recent Sci Res. 2017;8(9):19959-62. doi:10.24327/ijrsr.2017.0809.0795

50. Forbes WM, Gallimore WA, Mansingh A, Reese PB, Robinson RD. Eryngial (trans-2-dodecenal), a bioactive compound from Eryngium foetidum: its identification, chemical isolation, characterization and comparison with ivermectin in vitro. Parasitology. 2014;141(2):269-78. doi:10.1017/s003118201300156x

51. Homer S, Baccus-Taylor GSH, Akingbala JA. Antibacterial Efficacy of Eryngium foetidum (Culantro) against Select Food-borne Pathogens. In: Hutchinson SD, editor. Proceedings of the 27th West Indies Agricultural Economics Conference. 2007 Jul; Belize City, Belize. St. Augustine (TT): Caribbean Agro-Economic Society; 2007. p. 179-92.

52. Begum S, Ahmaruzzaman M, Adhikari PP. Ecofriendly bio-synthetic route to synthesize $\mathrm{ZnO}$ nanoparticles using Eryngium foetidum L. and their activity against pathogenic bacteria. Mater Lett. 2018;228:37-41. doi:10.1016/j.matlet.2018.05.091

53. Altemimi A, Lakhssassi N, Baharlouei A, Watson DG, Lightfoot DA. Phytochemicals: Extraction, Isolation, and Identification of Bioactive Compounds from Plant Extracts. Plants. 2017;6(4):42. doi:10.3390/plants6040042

54. Tchuenguem RT, Kechia FA, Kuiate JR, Dzoyem JP. Ethnopharmacological survey, antioxidant and antifungal activity of medicinal plants traditionally used in Baham locality (Cameroon) to treat fungal infections. Arch Med Biomed Res. 2017;3(2):91-103. doi:10.4314/ambr.v3i2.5

55. Promkum C, Butryee C, TuntipopipatS, Kupradinun P. Anticlastogenic effect of Eryngium foetidum L. assessed by erythrocyte micronucleus assay. Asian Pac J Cancer Prev. 2012;13(7):3343-7. doi:10.7314/apjcp.2012.13.7.3343

56. Singh S, Singh DR, Banu S, Salim KM. Determination of bioactives and antioxidant activity in Eryngium foetidum L.: A traditional culinary and medicinal herb. Proc Natl Acad Sci India Sect B Biol Sci. 2013;83:453-60. doi:10.1007/s40011-012-0141-y

57. Chandira RM, Jaykar B. Extraction, Pharmacological Evaluation and Formulation of Selected Medicinal Herbs for Antidiabetic Activity. Int J Pharm Teach Pract. 2013;4(1):458-82.

58. Kusirisin W, Srichairatanakool S, Lerttrakarnnon P, Lailerd N, Suttajit M, Jaikang C, et al. Antioxidative activity, polyphenolic content and anti-glycation effect of some Thai medicinal plants traditionally used in diabetic patients. Med Chem. 2009;5(2):13947. doi:10.2174/157340609787582918

59. Offiah NV, Seaforth CE, Sampath S, Rajack R, Mohammed A. An evaluation of the blood glucose lowering effects of Eryngium foetidum. In: Clement YN, Seaforth CE, editors. Proceedings of the Advancing Caribbean herbs in the 21st century. 2005 Jun 23-26; Rodney Bay, Saint Lucia. St. Augustine (TT): University of the West Indies; 2006. p. 30-5.

60. Kvist LP, Christensen SB, Rasmussen HB, Mejia K, Gonzalez A. Identification and evaluation of Peruvian plants used to treat malaria and leishmaniasis. J Ethnopharmacol. 2006;106(3):390402. doi:10.1016/j.jep.2006.01.020

61. Roumy V, Garcia-Pizango G, Gutierrez-Choquevilca A-L, Ruiz L, Jullian V, Winterton P, et al. Amazonian plants from Peru used by Quechua and Mestizo to treat malaria with evaluation of their activity. J Ethnopharmacol. 2007;112(3):482-9. doi:10.1016/j.jep.2007.04.009

62. Ruiz L, Ruiz L, Maco M, Cobos M, GutierrezChoquevilca A-L, Roumy V. Plants used by native Amazonian groups from the Nanay River (Peru) for the treatment of malaria. J Ethnopharmacol. 2011;133(2):917-21. doi:10.1016/j.jep.2010.10.039

63. Mariath IR, Falcão HdS, Barbosa-Filho JM, de Sousa LCF, Tomaz ACdA, Batista LM, et al. Plants of the American continent with antimalarial activity. Rev Bras Farmacogn. 2009;19(1a):185-92. doi:10.1590/S0102-695X2009000100026

64. Rojas-Silva P, Graziose R, Vesely B, Poulev A, Mbeunkui F, Grace MH, et al. Pharm Biol. 2014;52(3):398-401. doi:10.3109/13880209.2013.837077

65. Forbes WM, Steglich C, inventors. Slippery Rock University of Pennsylvania, Slippery Rock, 
Philadelphia, US, assignee. Methods of treating infectious diseases. International Patent (US) 20090047342. 2007-08-15.

66. Segarra-Newnham M. Manifestations, diagnosis, and treatment of Strongyloides stercoralis infection. Ann Pharmacother. 2007;41(12):1992-2001. doi:10.1345/aph.1k302

67. Quignard ELJ, Pohlit AM, Nunomura SM, Pinto ACdS, dos Santos EVM, de Morais SKR, et al. Screening of plants found in Amazonas State for lethality towards brine shrimp. Acta Amaz. 2003;33(1):93-104. doi:10.1590/1809-4392200331104

68. Liu M, Panda SK, Luyten W. Plant-Based Natural Products for the Discovery and Development of Novel Anthelmintics against Nematodes. Biomolecules. 2020;10(3):426. doi:10.3390/biom10030426

69. Sumitha KV, Prajitha V, Sandhya VN, Anjana S, Thoppil JE. Potential Larvicidal Principles in Eryngium foetidum L. (Apiaceae), An Omnipresent Weed, Effective Against Aedes albopictus Skuse. J Essent Oil-Bear Plant. 2014;17(6):1279-86. doi:10.1080/0972060X.2014.958544

70. Mangalat S, Narayanan V, Janardhanan M. Herbal larvicides to control mosquito larvae: A preliminary study. Nat Prod Radiance. 2004;3(1):24-6.

71. Kumar S, Madaan R, Bansal G, Jamwal A, Sharma A. Plants and Plant Products with Potential Anticonvulsant Activity - A Review. Pharmacogn Commun. 2012;2(1s):3-99. doi:10.5530/pc.2012.suppl1.2

72. Júnior LJQ Almeida JRGS, Lima JT, Nunes $X P$, Siqueira JS, de Oliveira LEG, et al. Plants with anticonvulsant properties: a review. Rev Bras Farmacogn. 2008;18(Suppl):789-819. doi:10.1590/S0102-695X2008000500026

73. Nsour WM, Lau CB, Wong IC. Review on phytotherapy in epilepsy. Seizure. 2000;9(2):96-107. doi:10.1053/seiz.1999.0378

74. Chakraverty R, Nath N, Debnath T, Ghosh A, Datta S. Pharmacological Assessment of the Hydroalcoholic Extracts of Leaves of Eryngium foetidum Linn. (EFHA). Int J Curr Trend Pharmacobiol Med Sci. 2016;1(2):75-80.

75. Rodrigues E. Plants of restricted use indicated by three cultures in Brazil (Caboclo-river dweller, Indian and Quilombola).J Ethnopharmacol. 2007;111(2):295302. doi:10.1016/j.jep.2006.11.017

76. Janwitthayanuchit K, Kupradinun P, Rungsipipat A, Kettawan A, Butryee C. A 24-Weeks Toxicity Study of Eryngium foetidum Linn. Leaves in Mice. Toxicol Res. 2016;32(3):231-7. doi:10.5487/tr.2016.32.3.231 